\title{
Evidence for chemoautotrophic symbiosis in a Mediterranean cold seep clam (Bivalvia: Lucinidae): comparative sequence analysis of bacterial $16 S$ rRNA, APS reductase and RubisCO genes
}

\author{
Sébastien Duperron ${ }^{1,2,3^{*}}$, Aline Fiala-Médioni ${ }^{4,}$ \\ Jean-Claude Caprais ${ }^{2}$ Karine Olu $^{2}$ and Myriam Sibuet ${ }^{2}$
}

\begin{abstract}
1 UMR 7138, Adaptation aux milieux extrêmes, Université Pierre et Marie Curie, 7 quai St Bernard, 75005 Paris, France

2 Ifremer, Laboratoire environnement profond, Centre de Brest, BP 70, 29263 Plouzané, France

3 Max Planck Institute for Marine Microbiology, Celsiusstr. 1, D-28359, Bremen, Germany

4 Observatoire Océanologique, Université Pierre et Marie Curie, BP 44, 66651, Banyuls-sur-mer Cedex, France

*: Corresponding author : sduperro@snv.jussieu.fr
\end{abstract}

\begin{abstract}
:
Symbioses between lucinid clams (Bivalvia: Lucinidae) and autotrophic sulphide-oxidizing bacteria have mainly been studied in shallow coastal species, and information regarding deep-sea species is scarce. Here we study the symbiosis of a clam, resembling Lucinoma kazani, which was recently collected in sediment cores from new cold-seep sites in the vicinity of the Nile deep-sea fan, eastern Mediterranean, at depths ranging from 507 to $1691 \mathrm{~m}$. A dominant bacterial phylotype, related to the sulphide-oxidizing symbiont of Lucinoma aequizonata, was identified in gill tissue by comparative $16 \mathrm{~S}$ rRNA gene sequence analysis. A second phylotype, related to spirochete sequences, was identified twice in a library of 94 clones. Comparative analyses of gene sequences encoding the APS reductase a subunit and ribulose-1,5-bisphosphate carboxylase oxygenase support the hypothesis that the dominant symbiont can perform sulphide oxidation and autotrophy. Transmission electron micrographs of gills confirmed the dominance of sulphide-oxidizing bacteria, which display typical vacuoles, and $\delta 13 \mathrm{C}$ values measured in gill and foot tissue further support the hypothesis for a chemoautotrophicsourced host carbon nutrition.
\end{abstract}




\section{Introduction}

Lucinid clams are infaunal bivalves which live in reduced sediment in both shallow coastal waters as well as at deep-sea cold seeps. Lucinids display typical characteristics of symbiontassociated bivalves such as reduced gut and palps and large fleshy gills (Fiala-Médioni \& Felbeck 1990, Taylor \& Glover 2000). Hence, all investigated species are associated with symbiotic bacteria found in specialized epithelial cells named bacteriocytes. Symbiosis is often considered as the major factor shaping the evolution within the family Lucinidae since its emergence in the Jurassic (Little \& Vrijenhoek 2003).

Due to ease of access, most information regarding symbiosis in lucinids has been obtained from species collected in shallow, coastal sediments (for review see Fiala-Médioni \& Felbeck 1990, Fisher 1990). Despite attempts (Wood \& Kelly 1989), symbionts have not been successfully grown separately from their host (Cary et al. 1989). However, indirect evidence based on enzyme assays and transmission electron microscopy (TEM) indicate that symbionts are autotrophic sulphideoxidizing bacteria (Felbeck et al. 1981). In oxygen-depleted environments, symbionts of some species can avoid competition with their host for oxygen resources by growing on nitrate (Duplessis et al. 2004), indicating the existence of environment-specific adaptation or physiological responses. Phylogenetic characterization of the symbionts has shown that they belong to the Gammaproteobacteria class, and are related to symbionts from thyasirid and solemyid bivalves as well as symbionts from siboglinid tubeworms (Stewart et al. 2005). Host-symbiont specificity is questionable, as several host species of genuses Codakia and Lingua collected from similar habitats harbour the same 16S rRNA bacterial phylotype (Durand \& Gros 1996, Durand et al. 1996); environmental transmission of bacteria has been demonstrated in $C$. orbicularis in experimental systems (Gros et al. 1996, Gros et al. 2003); and free -living forms of the symbionts were identified in seagrass beds in the clam's habitat (Gros et al. 2003).

Although deep-sea cold seep species of lucinids are known, mainly from empty shells evidence (for review, see Sibuet \& Olu 1998), data regarding their symbioses is comparatively scarce. This is due to the infaunal habitat of lucinids, preventing observation and specific collection of living specimens on the sea floor. Lucinoma kazani was recently described based on few living specimens recovered from gas-saturated sediments at Kazan mud volcano $(1709 \mathrm{~m}$ depth, eastern Mediterranean) (Salas \& Woodside 2002, Olu-LeRoy et al. 2004). This species was suggested to harbour sulphide-oxidizing symbionts based on scanning electron micrographs, but this hypothesis was not tested (Salas \& Woodside 2002). During the Nautinil cruise in 2003, several new cold seep sites were discovered and explored in the vicinity of the Nile deep sea fan. Specimens of a lucinid resembling L. kazani (based on shell morphology) were sampled from sediment cores on the North Alex and Isis mud volcanoes, and from pockmarks in the central area, allowing to investigate symbiosis in more details. In this study, we describe the bacterial symbionts and their phylogenetic relationship to other lucinid symbionts by comparative 16S rRNA sequence analysis, and we assess their metabolic potential by sequencing target functional genes encoding proteins involved in the sulphide oxidation pathway (APS reductase) and in carbon fixation using the Calvin Benson cycle (Ribulose 1,5 bisphosphate carboxylase oxygenase or RubisCO). The structure of the association and its nutritional role are investigated using TEM and stable isotope analysis. 


\section{Materials and Methods}

Samples

Specimens of lucinid clams resembling Lucinoma kazani (Salas \& Woodside 2002) and herein referred as Lucinoma aff. kazani were collected using the manned submersible Nautile during the Nautinil cruise to the eastern Mediterranean (2003, chief scientist: J. P. Foucher). These bivalves were buried in sediments, below the oxic/anoxic interface. Two specimens from a sediment core collected on the North Alex mud volcano (31 ${ }^{\circ} 58.2^{\prime} \mathrm{N} 30^{\circ} 08.2^{\prime} \mathrm{E}, 507 \mathrm{~m}$ depth) were dissected and stored in liquid nitrogen for DNA studies and stable isotope measurements. Gill tissue of two specimens from pockmarks of the Central area $\left(32^{\circ} 31.6 \mathrm{~N}, 30^{\circ} 20.7^{\prime} \mathrm{E}, 1691 \mathrm{~m}\right.$ depth, dive NL7) and on ISIS mud volcano $\left(32^{\circ} 21.7^{\prime} \mathrm{N}, 31^{\circ} 23.4^{\prime} \mathrm{E}, 990 \mathrm{~m}\right.$ depth, dive NL8) was fixed for transmission electron microscopy (TEM, see below).

\section{Methane measurements}

To confirm the presence of methane in the sediment two $750 \mathrm{~mL}$ water samples were collected a few centimetres above the seafloor; using titanium syringes coupled to a funnel. Methane concentrations were measured onboard by gas chromatography according to the protocol described in Sarradin \& Caprais 1996.

\section{Gene amplification, cloning and sequencing}

DNA was extracted from the gill tissue of the two North Alex specimens using a FastDNA® SPIN KitPrep (Qbiogene, CA). The gene encoding 16S rRNA was amplified from each specimen as described elsewhere (Duperron et al. 2005). Fragments of functional genes sequences were amplified from both individuals. Due to limited amounts of amplified DNA, PCR products were pooled prior to cloning. A $395 \mathrm{bp}$ fragment of the gene encoding the alpha subunit of the APS reductase was amplified using primers APS1-FW and APS4-RV (Deplancke et al. 2000). An initial denaturation step $\left(92^{\circ} \mathrm{C}, 4 \mathrm{~min}\right)$ was followed by 33 cycles at $92^{\circ} \mathrm{C}(1 \mathrm{~min}), 58^{\circ} \mathrm{C}(1 \mathrm{~min})$ and $72^{\circ} \mathrm{C}(1 \mathrm{~min})$. The reaction ended with a final elongation step at $72^{\circ} \mathrm{C}(10 \mathrm{~min})$. A $691 \mathrm{bp}$ fragment of the gene encoding RubisCO form I was amplified using primers cbbl1b and cbbl2c (Elsaied \& Naganuma 2001). Denaturation step was followed by 33 cycles at $92^{\circ} \mathrm{C}(1 \mathrm{~min}), 48^{\circ} \mathrm{C}(1,5 \mathrm{~min})$ and $72^{\circ} \mathrm{C}(1 \mathrm{~min})$. A final elongation step was added. The presence of a particulate methane monooxygenase alpha subunit gene $(p m o A)$ was tested by amplifying a gene fragment using the PCR protocol described in Holmes et al. 1995. PCR products were purified using a kit (QIAGEN, Germany) and cloned with a TOPO-TA cloning kit (Invitrogen, California). Inserts were partially sequenced using a vector-specific primer. For 16S rRNA, 94 clones were partially sequenced (47 from each individual), and 25 fully sequenced. A total of 19 APS and 12 RubisCO clones were fully sequenced.

\section{Sequence analysis and phylogenetic reconstruction}

Nucleotide sequences of $16 \mathrm{~S}$ rRNA, and amino acid sequences of APS reductase and RubisCO were compared with sequences available from the EMBL database using BLAST (Altschul et al. 1990). Sequences displaying highest similarities as well as representative sequences for known groups were included in further analyses. Sequences were aligned using ClustalX. Phylogenetic analyses of the 16S rRNA sequences were run with TreeFinder (Jobb 2003) using the maximum likelihood method and a general time reversible model. RELL values from the 1000 best trees were used as support values for the nodes. Phylogenies of the APS and Rubisco genes were reconstructed with the PHYLIP package (Felsenstein 2002) using a maximum likelihood method with a JTT model. Bootstrap values were obtained using the same method.

\section{Transmission electron microscopy}

Sample fixation, inclusion and sectioning were performed according to the procedure described in Duperron et al. 2005. After addition of uranyl acetate, ultrathin sections were observed with an HITACHI H-7500 transmission electron microscope.

\section{Stable isotope analysis}

Frozen gill and foot tissue from a specimen were acidified in $0.1 \mathrm{~N} \mathrm{HCl}$, rinsed, and dessiccated in a $46^{\circ} \mathrm{C}$ chamber. After grinding, stable isotope values of nitrogen and carbon were measured in a Finnigan Delta $\mathrm{S}$ isotope ratio mass spectrometer. 
Sequence accession numbers

Nucleotide sequences were deposited in the EMBL database under accession numbers AM236336 and AM236337 (16S rRNA sequences), AM236338 (APS sequence), AM236339 and AM236340 (RubisCO sequences).

\section{Results and Discussion}

A total of 94 partial 16S rRNA sequences were obtained from the two lucinid clams, representing two distinct bacterial phylotypes. The dominant phylotype, 92 of the 94 sequences, belongs to a Gammaproteobacterium. The occurrence of a unique Gammaproteobacterial 16S rRNA phylotype is supported by the very low level of variation between sequences $(<0.2 \%)$, and by the absence of shared nucleotide substitutions (Duperron et al. in press). This phylotype shares $97 \%$ sequence identity with the thiotrophic symbiont of Codakia costata, a coastal lucinid from sediments in shallow tropical areas (Distel et al. 1994). The second phylotype occured twice in the clone library from one of the specimens and is similar to clone Nubeena322, a spirochete partial 16S rRNA sequence recovered from marine sediments ( $91 \%$ identity, short sequence not included in the phylogenetic reconstruction). The phylogenetic tree (Fig. 1) resembles that presented by Durand and co-workers (Durand et al. 1996), with symbionts of Thyasira flexuosa, Lucina pectinata and Anodontia phillipiana branching at the base of the clade containing sequences from symbionts of thyasirids and lucinids. Symbionts from siboglinid tubeworms also cluster within this group. The Gammaproteobacterial phylotype appears in a well-supported clade containing symbionts of lucinids, and is closely related to the symbiont of Lucinoma aequizonata, a clam collected in reduced sediment at a depth of $500 \mathrm{~m}$ off the coast of California (Distel et al. 1988). Therefore it is likely that it belongs to a bacterial symbiont. The spirochete-related phylotype clusters with Spirochaeta coccoides, a coccoidshaped spirochete recently discovered in the hindgut of a termite (Dröge et al. 2006). It is not closely related to spirochete symbionts previously identified in the oligochetes Olavius algarvensis and 0 . ilvae (Dubilier et al. 1999, Blazejak et al. 2005), nor is it to Cristispira, a large spirochete identified in the cristalline style of oysters (Margulis et al. 1991, Paster et al. 1996).

A single APS alpha subunit sequence was retrieved. It shares $90 \%$ amino-acid identity to that of the Betaproteobacterium Thiobacillus denitrificans, its closest relative in the tree, together with a clone from the intestinal tract of a mouse (Fig. 2). The sequence does not cluster with the APS sequence from the Gammaproteobacterium Allochromatium vinosum. This relationship might indicate that the sequence derives from a contaminating, non-symbiotic, bacterium from the environment. However, events of lateral transfer of the ApsA gene, which have been reported in sulphate-reducing bacteria (Friedrich 2002), could explain the discrepancy in the tree if the APS sequence actually belongs to the gammaproteobacterial symbiont. This hypothesis is further supported by the fact that APS reductase activities have been measured in many lucinid clam gills (Felbeck et al. 1981, Dando et al. 1985, Spiro et al. 1986). Spirochetes are not known to possess APS reductase, and no significant result were obtained from 'blasting' APS amino acid sequences against the 6 available spirochete complete genomes. It is therefore unlikely that the APS sequence belongs to the putative spirochete symbiont.

Two closely related RubisCO form IA sequences were recovered $(>98.5 \%$ and $>97.0 \%$ base and aminoacid identity, respectively), both displaying $96 \%$ amino acid identity to the sequence of the Solemya velum thiotrophic endosymbiont which appeared as their closest relative in the tree (Fig. 3) (Schwedock et al. 2004). These sequences cluster within a clade that includes RubisCO form IA sequences from chemoautotrophic symbionts associated with molluscs. This supports the hypothesis that they derive from the thiotroph-related symbionts and not from a contaminating bacterium. Alternatively, they could originate from the spirochete putative symbiont, and although autotrophy has been reported in spirochetes (Madigan et al. 2002), no spirochete sequence resembling RubisCO could be retrieved using Blast. The occurence of two related APS sequences might indicate the presence of two distinct symbiont strains even though they were not distinguished based on their 16S rRNA sequence. No amplification could be obtained for pmoA.

TEM observations on gill sections (Fig. 4) indicate the presence of numerous inclusions, 0.65 to $1.04 \mu \mathrm{m}$ diameter $(n=14)$, resembling bacterial symbionts reported in other lucinids (see for example Gros et al. 2003). Bacteria occur in vacuoles containing one or two individuals which occupy most of the volume within specialised bacteriocytes. Symbionts lack any internal membrane system such as observed in methanotrophs (Anthony 1982), but display electron lucent vesicles which are interpreted as sulphur granules in other species (Vetter 1985). No morphotype resembling typical spirochetes was seen, suggesting that the retrieved spirochete 16S rRNA phylotype came from an environmental 
contaminant. However, the recovered phylotype is related to an unusual coccoid-shaped spriochete Spirochaeta coccoides (Dröge et al. 2006), so perhaps this bacterium simply does not display the typical spirochete morphology.

Carbon isotopic signatures of $-30.5 \%$ and $-28.2 \%$ were measured in the gill and foot tissue of a specimen. These values are in the range of values reported elsewhere for lucinids harbouring thiotrophic symbionts (reviewed in Fisher 1990), and further support the hypothesis for a carbon nutrition source based on bacterial chemoautotrophy.

Our results suggest that the dominant gill endosymbiont of Lucinoma aff. kazani is a Gammaproteobacterium which likely possesses APS reductase- and RubisCO-encoding genes. Larger fragments surrounding these genes should be sequenced to conclude this definitely. To date all lucinids investigated from both coastal and deep sea environments, at least 30 species from 18 different genera, were shown to harbour this type of symbiosis, although we provide the first APS reductase and RubisCO gene sequences (Taylor \& Glover 2000). In this study, we report for the first time a 16S rRNA spirochete sequence from the gill tissue of a lucinid. We provide no evidence that spirochetes actually occur as symbionts in lucinids, but spirochete symbionts, not closely related to the sequence herein described, are known to occur in oligochetes (Dubilier et al. 1999, Blazejak et al. 2005). Further work should investigate the true status of spirochetes in lucinids, for example using fluorescence in situ hybridization techniques.

Sediments at the North Alex mud volcano are rich in methane. Gas bubbles were observed (A. Prinzhofer, pers. comm.), and methane concentrations of 34 and $640 \mu \mathrm{M}$ were measured from two water samples collected just above the seafloor. This indicates the presence of methane in the underlying sediment. The occurrence of Lucinoma aff. kazani might be related to local enrichments in sulphide due to the activity of microbial consortia mediating the anaerobic oxidation of methane coupled to sulphate reduction (Boetius et al. 2000). The L. kazani shell morphotype also occurs at several cold seep sites in the Eastern Mediterranean (Salas \& Woodside 2002, Olu-LeRoy et al. 2004). Investigating the distribution of this lucinid and the degree of phylogenetic relatedness between populations of hosts and symbionts would greatly improve our knowledge of the biogeography and evolution of symbiosis in deep-sea lucinids, which are currently poorly documented compared to coastal species.

\section{Acknowledgements}

We gratefully acknowledge crew and pilots of the RV L'Atalante and the submarine Nautile, as well as the scientists involved in the Nautinil cruise (Ifremer, chief scientist: J. P. Foucher). Thanks to N. Dubilier for her help. We thank V. Cueff-Gauchard, E. Roussel, B. Rivière and D. Saint-Hilaire for their technical assistance. F. Gaill, L. Anderson and O. Gros helped to improve the manuscript with their corrections and comments. S. D. is funded by MPI, Ifremer, UPMC and CNRS (UMR 7138). 
Altschul SF, Gish W, Miller W, Myers EW, Lipman DJ (1990) Basic local alignment search tool. Mol Biol 215:403-410

Anthony C (1982) The biochemistry of methylotrophs, Vol, London

Blazejak A, Erseus C, Amann R, Dubilier N (2005) Coexistence of Bacterial Sulfide Oxidizers, Sulfate Reducers, and Spirochetes in a Gutless Worm (Oligochaeta) from the Peru Margin. Appl Environ Microbiol 71:1553-1561

Boetius A, Ravenschlag K, Schubert CJ, Rickert D, Widdel F, Gieseke A, Amann R, Jorgensen BB, Witte U, Pfannkuche O (2000) A marine microbial consortium apparently mediating anaerobic oxidation of methane. Nature 407:623-626

Cary SC, Vetter RD, Felbeck H (1989) Habitat characterization and nutritional strategies of the endosymbiont-bearing Lucinoma aequizonata. Mar Ecol Prog Ser 55:31-45

Dando PR, Southward AJ, Southward EC, Terwilliger NB, Terwilliger RC (1985) Sulphur-oxidizing bacteria and haemoglobin in gills of the bivalve mollusc Myrtea spinifera. Mar Ecol Prog Ser 23:85

Deplancke B, Hristova KR, Oakley HA, McCracken VJ, Aminov R, Mackie RI, Gaskins HR (2000) Molecular Ecological Analysis of the Succession and Diversity of Sulfate-Reducing Bacteria in the Mouse Gastrointestinal Tract. Appl Environ Microbiol 66:2166-2174

Distel D, Felbeck H, Cavanaugh C (1994) Evidence for phylogenetic congruence among sulfuroxidizing chemoautotrophic bacterial endosymbionts and their bivalve host. J Mol Evol 38:533542

Distel D, Lane D, Olsen G, Giovannoni S, Pace B, Pace N, Stahl D, Felbeck H (1988) Slfur-oxidizing bacterial endosymbionts - Analysis of phylogeny and specificity by $16 \mathrm{~S}$ ribosomal RNA sequences. J Bacteriol 170:2506 - 2510

Dröge S, Frölich J, Radek R, König H (2006) Spirochaeta coccoides sp. nov., a novel coccoid spirochete from the hindgut of the termite Neotermes castaneus. Appl Env Microbiol 72:392397

Dubilier N, Amann R, Erseus C, Muyzer G, Park Sue Y, Giere O, Cavanaugh CM (1999) Phylogenetic diversity of bacterial endosymbionts in the gutless oligochete Olavius loisae (Annelida). Mar Ecol Prog Ser 178:271-280

Duperron S, Bergin C, Zielinski F, McKiness ZP, DeChaine EG, Cavanaugh CM, Dubilier N (in press) A dual symbiosis shared by two mussel species, Bathymodiolus azoricus and Bathymodiolus puteoserpentis (Bivalvia: Mytilidae), from hydrothemal vents along the northern Mid-Atlantic Ridge. Environ Microbiol

Duperron S, Nadalig T, Caprais JC, Sibuet M, Fiala-Médioni A, Amann R, Dubilier N (2005) Dual symbiosis in a Bathymodiolus mussel from a methane seep on the Gabon continental margin (South East Atlantic): 16S rRNA phylogeny and distribution of the symbionts in the gills. Appl Environ Microbiol 71:1694-1700

Duplessis MR, Ziebis W, Gros O, Caro A, Robidart J, Felbeck H (2004) Respiration strategies utilized by the gill endosymbiont from the host lucinid Codakia orbicularis (Bivalvia: Lucinidae). Appl Environ Microbiol 70:4144-4150

Durand P, Gros O (1996) Bacterial host specificity of Lucinacea endosymbionts: interspecific variation in 16S rRNA sequences. FEMS Microbiology Letters 140:193-198

Durand P, Gros O, Frenkiel L, Prieur D (1996) Phylogenetic characterization of sulfur-oxidizing bacterial endosymbionts in three tropical Lucinidae by $16 \mathrm{~S}$ rDNA sequence analysis. Molecular Mar Biol and Biotechnology 5:37-42

Elsaied HE, Naganuma T (2001) Phylogenetic diversity of ribulose-1,5-bisphosphate carboxylase/oxygenase large subunit genes from deep-sea microorganisms. Appl Environ Microbiol 67:1751-1765

Felbeck H, Childress JJ, Somero GN (1981) Calvin-Benson cycle and sulphide oxidation enzymes in animals from suplhide-rich habitats. Nature 293:291

Felsenstein J (2002) PHYLIP (Phylogeny Inference Package). Distributed by the author. Department of Genome Sciences, University of Washington, Seattle

Fiala-Médioni A, Felbeck H (1990) Autotrophic processes in invertebrate nutrition: Bacterial symbiosis in bivalve Molluscs. In: Kinne RKH, Kinne-Saffran E, Beyenbach KW (eds) Comparative Physiology, Vol 5. Karger, p 49-69

Fisher CR (1990) Chemoautotrophic and methanotrophic symbioses in marine invertebrates. Reviews in Aquatic Sciences 2:399-613

Friedrich MW (2002) Phylogenetic analysis reveals multiple lateral transfers of adenosine-5'phosphosulfate reductase genes among sulfate-reducing microorganisms. J Bacteriol 184:278-289 
Gros O, Darrasse A, Durand P, Frenkiel L, Mouëza M (1996) Environmental transmission of a sulfuroxidizing bacterial gill endosymbiont in the tropical lucinid bivalve Codakia orbicularis. Appl Environ Microbiol 62:2324-2330

Gros O, Liberge M, Felbeck H (2003) Interspecific infection of aposymbiotic juveniles of Codakia orbicularis by various tropical lucinid gill-endosymbionts. Mar Biol 142:57-66

Gros O, Liberge M, Heddi A, Kherchadourian C, Felbeck H (2003) Detection of the free-living forms of sulfide-oxidizing gill endosymbionts in the lucinid habitat (Thalassia testudinum environment). Appl Environ Microbiol Oct.:6254-6257

Holmes AJ, Costello A, Lidstrom ME, Murrell JC (1995) Evidence that particulate methane monooxygenase and ammonia may be related. FEMS Microbiol Lett 132:203-208

Jobb G (2003) TREEFINDER version March 2003. Munich, Germany Distributed by the author at www.treefinder.de

Little CTS, Vrijenhoek RC (2003) Are hydrothermal vent animals living fossils? Trends in Ecology and Evolution 18:582-588

Madigan MT, Martinko JM, Parker J (2002) Brock Biology of Microorganisms. Pearson Education

Margulis L, Nault L, Sieburth J (1991) Cristispira from oyster styles: complex morphology of large symbiotic spirochetes. Symbiosis 11:1-19

Olu-LeRoy K, Sibuet M, Fiala-Médioni A, Gofas S, Salas C, Mariotti A, Foucher JP, Woodside J (2004) Cold seep communities in the deep eastern Mediterranean Sea: composition, symbiosis, and spatial distribution on mud volcanoes. Deep-Sea Res I 51:1915-1936

Paster BJ, Pelletier BA, Dewhirst FE, Weisburg WG, Fussing V, Poulsen LK, Dannenberg S, Schroeder I (1996) Phylogenetic position od the spirochetal genus Cristispira. Appl Environ Microbiol 62:942-946

Salas C, Woodside J (2002) Lucinoma kazani n. sp. (Mollusca: Bivalvia): evidence of a living benthic community associated with a cold seep in the Eastern Mediterranean Sea. Deep-Sea Research I 49:991-1005

Sarradin PM, Caprais JC (1996) Analysis of dissolved gases by headspace sampling gas chromatography with column and detector switching. Preliminary results. Analytical communications 33:371-373

Schwedock J, Hermer TL, Scott KM, Hektor HJ, Seitz AP, Fontana MC, Distel DL, Cavanaugh CM (2004) Characterization and expression of genes from the RubisCO gene cluster of the chemoautotrophic symbiont of Solemya velum: cbbLSQO. Arch Microbiol 182:18-29

Sibuet M, Olu K (1998) Biogeography, biodiversity and fluid dependance of deep sea cold seep communities at active and passive margins. Deep-Sea Research II 45:517 - 567

Spiro B, Greenwood PB, Southward AJ, Dando PR (1986) 13C/12C ratios in marine invertebrates from reducing sediments: confirmation of nutritional importance of chemoautotrophic endosymbiotic bacteria. Mar Ecol Prog Ser 28:233

Stewart FJ, Newton LG, Cavanaugh CM (2005) Chemosynthetic endosymbioses: adaptations to oxicanoxic interfaces. Trends Microbio 13:439-448

Taylor JD, Glover E (2000) Functional anatomy, chemosymbiosis and evolution of the Lucinidae. In: Harper EM, Taylor JD, Crame JA (eds) The evolutionary biology of the bivalvia, Vol 77, special publication. Geological Society, London, p 207-225

Vetter RD (1985) Elemental sulfur in the gills of three species of clams containing chemoautotrophic symbiotic bacteria: a possible inorganic energy storage compound. Mar Biol 88:33-42

Wood AP, Kelly DP (1989) Methylotrophic and autotrophic bacteria isolated from lucinid and thyasirid bivalves containing symbiotic bacteria in their gills. J Mar Biol Ass UK 69:165-179 


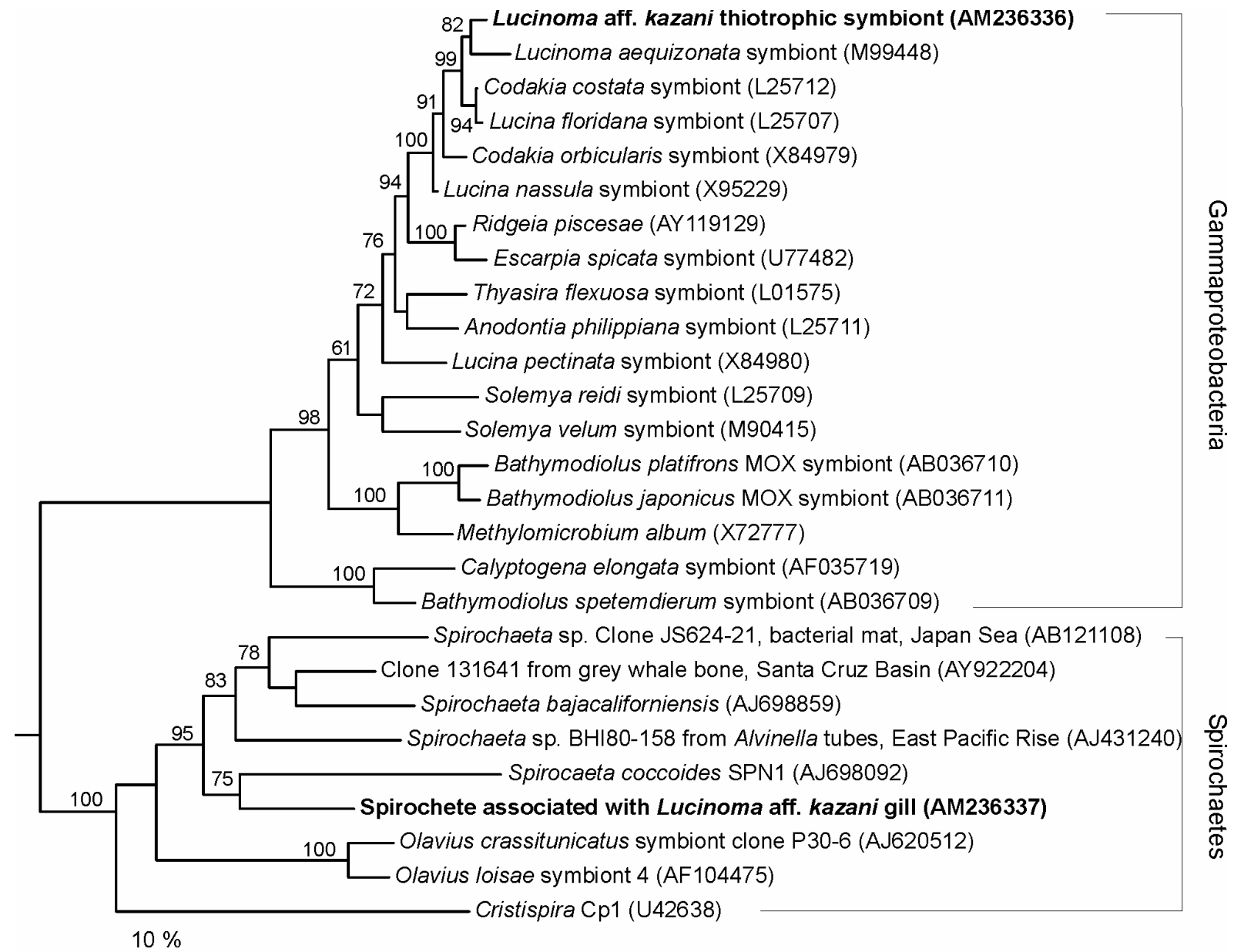

Fig. 1: Maximum likelihood tree displaying the phylogenetic relationships of symbiont from Lucinoma aff. kazani (in bold) to Gammaproteobacteria and spirochetes, based on 16S rRNA gene sequences (1240 nt positions). Tree was constructed using a GTR model, RELL values were obtained from the 1000 best trees (only $>60 \%$ shown), Likelihood: -12774 . Within Gammaproteobacteria, all symbionts are from putative sulphide oxidizers, except those labelled MOX (methane-oxidizers). Scale bar represents $10 \%$ estimated base substitution. 


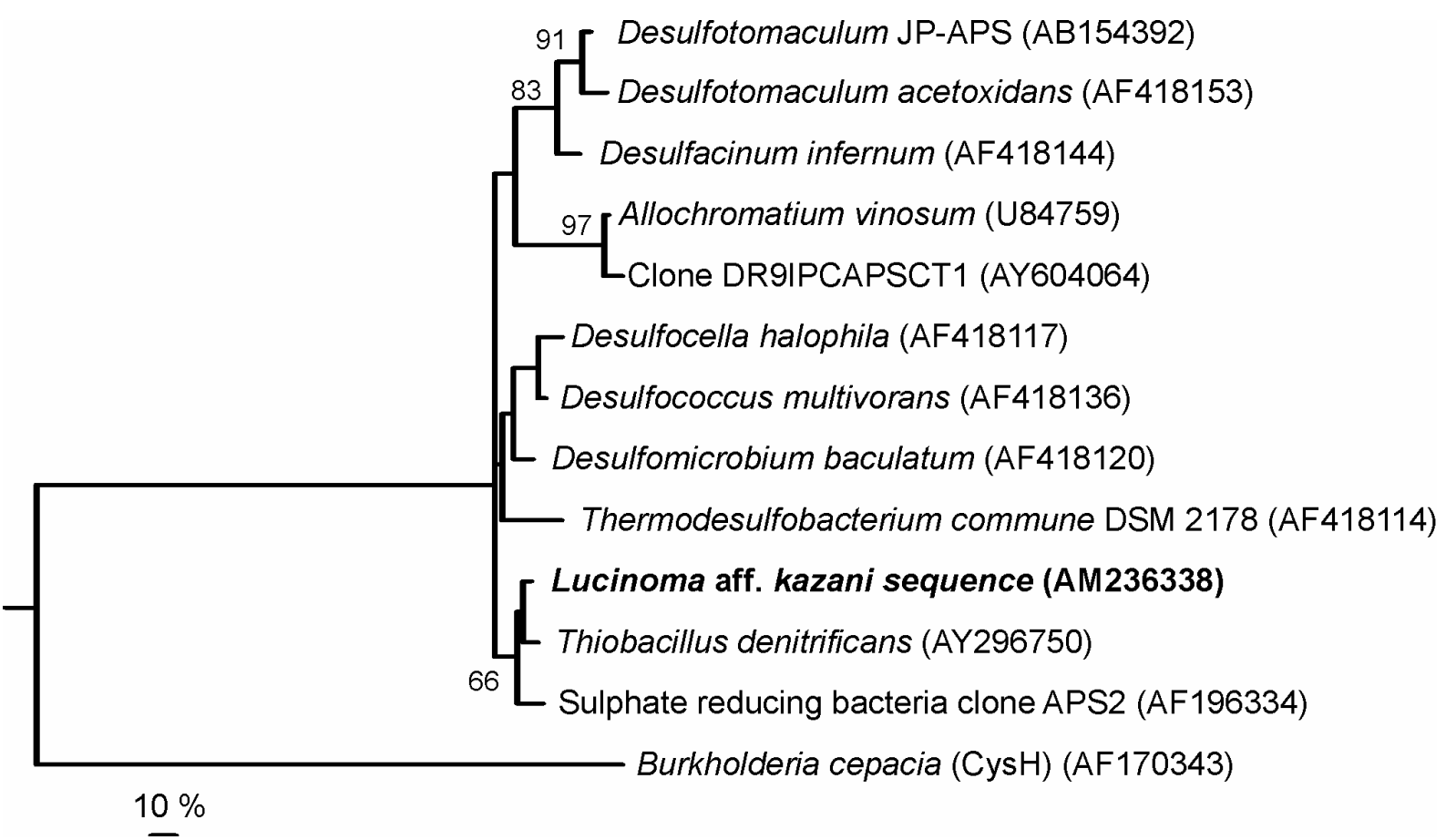

Fig. 2: Maximum likelihood tree displaying the phylogenetic position of the APS reductase alpha subunit sequence retrieved from Lucinoma aff. kazani (in bold). Tree was contructed based on 125 aa positions using a JTT model, sequence input order was randomized, bootstrap values were obtained from 500 replicates (only $>60 \%$ shown). Scale bar represents $10 \%$ estimated amino acid substitution. 


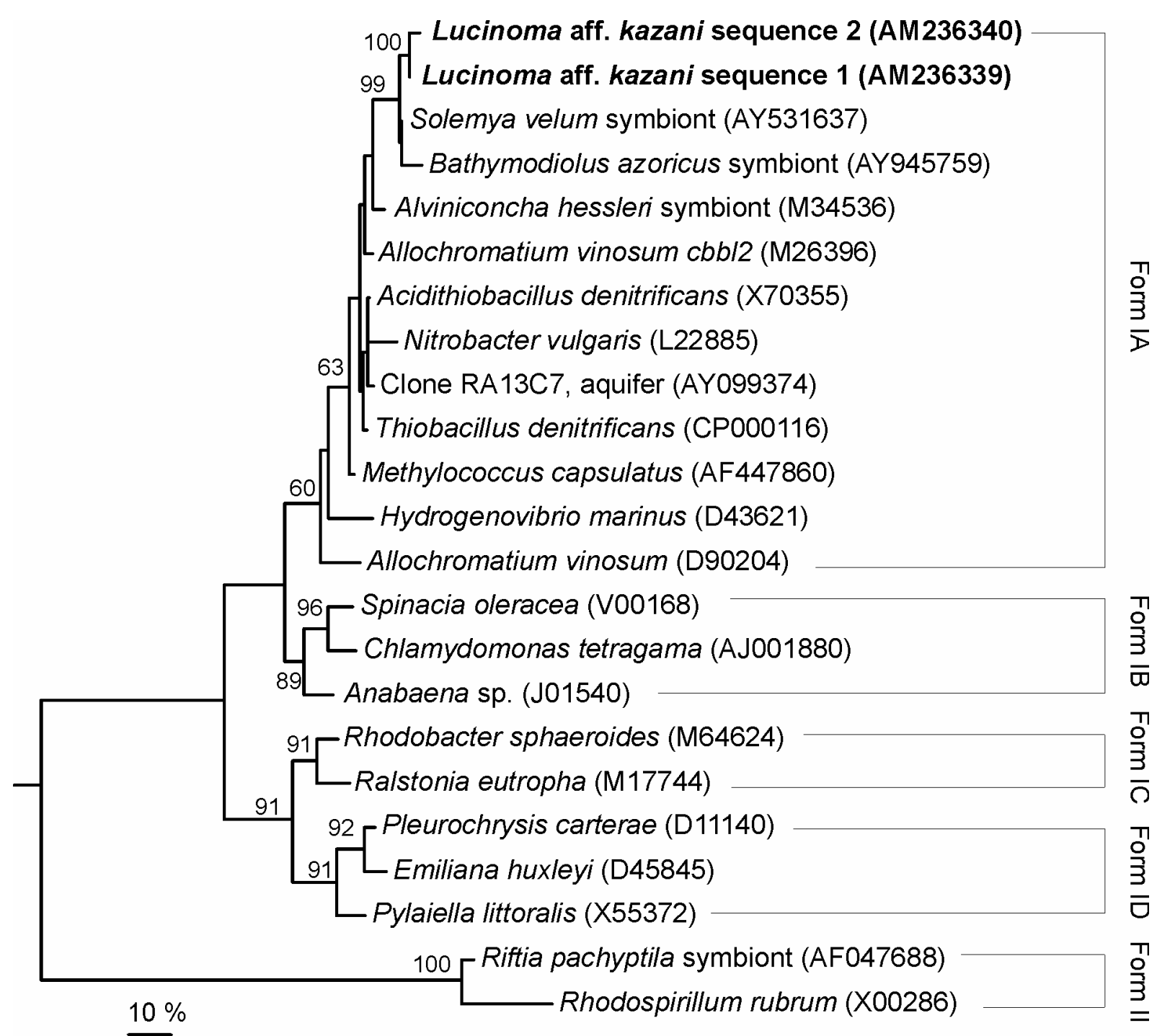

Fig. 3: Maximum likelihood tree displaying the phylogenetic position of the two RubisCO sequences retrieved from Lucinoma aff. kazani (in bold). Both sequences from $L$. aff kazani cluster together within the Form IA cluster, and are related to sequences from Gammaproteobacteria. Tree was contructed based on 230 aa positions using a JTT model, sequence input order was randomized, bootstrap values were obtained from 200 replicates (only $>60 \%$ shown). Scale bar represents $10 \%$ estimated amino acid substitution. 


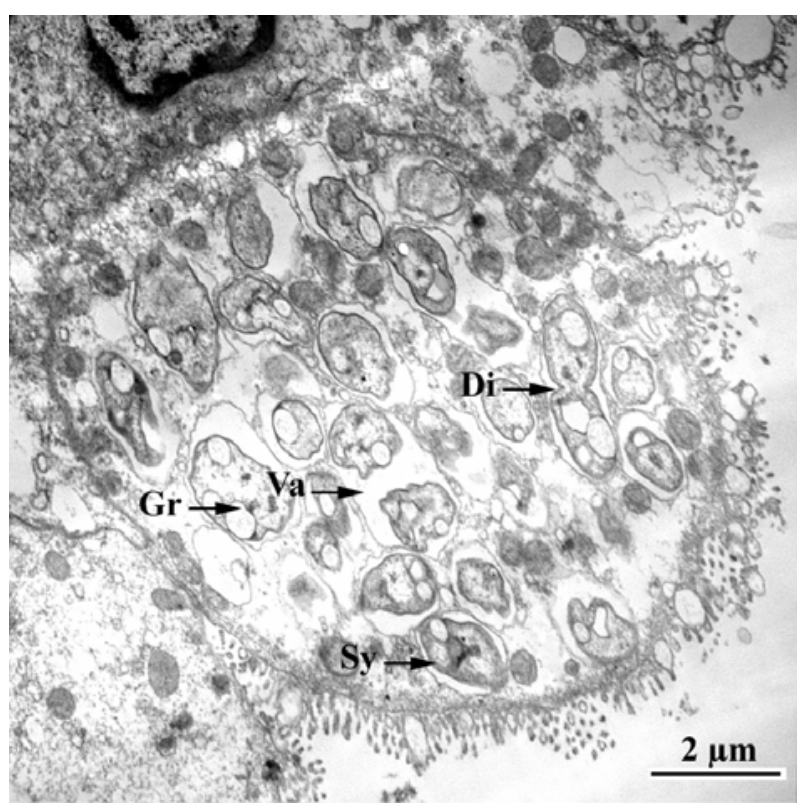

Fig. 4: TEM micrograph from a bacteriocyte within a gill of Lucinoma aff. kazani displaying symbionts (Sy) possessing empty vesicles previously described as remnants of sulfur granules (Gr). Symbionts are located in vacuoles (Va), and dividing stages occur (Di). Scale bar represents $2 \mu \mathrm{m}$. 